\title{
Third Head of the Biceps Brachii Muscle Originated from the Greater Tubercle Connecting Long and Short Heads: A Case Report
}

\author{
Tercera Cabeza del Músculo Bíceps Braquial Originada en la Tubrosidad Mayor \\ del Húmero Conectando las Cabezas Larga y Corta: Informe de un Caso
}

Yu-Ran Heo; Jae-Hee Park; In-Jang Choi \& Jae-Ho Lee

HEO, Y. R.; PARK, J. H.; CHOI, I. J. \& LEE, J. H. Third head of the biceps brachii muscle originated from the greater tubercle connecting long and short heads: A case report. Int. J. Morphol., 38(1):23-25, 2020.

SUMMARY: Variation in the biceps brachii muscle is extremely frequent and has a clinical significance. During an educational dissection, third head of the biceps brachii muscle was found on the left side in a Korean cadaver. The short and long heads showed normal morphology and course: however, additional head originated from the greater tubercle connected to long head of biceps brachii muscle and crossed the musculocutaneous nerve perpendicularly. And then, it was inserted into short head of the biceps brachii muscle. The author describes this previously novel case report and discusses the clinical implications of such a variant.

KEY WORDS: Biceps brachii muscle; Third head; Variation.

\section{INTRODUCTION}

The biceps brachii muscle (BBM) has two heads; a long head originates from the supraglenoid tubercle and a short head from the coracoid process of the scapula. In terms of the number and morphology of its heads, variations of $\mathrm{BBM}$ are extremely frequent muscles in the human body (Bergman et al., 1988; Asvat et al., 1993; Nakatani et al., 1998). The most common variation is a third head, but four, five, or even seven heads have been reported.

Recent study classified the type of the supernumerary heads into 3 types, as superior, infero-medial, and inferolateral according to their origin and location (RodríguezNiedenführ et al., 2003). In Korean population, many cases with supernumerary heads of BBM have been reported and its frequency and pattern were also studied (Lee JH et al., 2008; Lee et al., 2014; Je et al., 2016). However, there was no report with superior head of BBM in Korean populations.

In this case report, unique morphology of the third head of BBM was presented and we discussed the clinical and embryological significances of this variation.

\section{CASE REPORT}

During a routine dissection of the upper limb, variation of BBM was found on the left side of a 81year-old female cadaver (Fig. 1). After the skin, subcutaneous fat, and fascia were removed to expose BBM, the nerve and blood supply of each head were carefully examined. The findings were photographed, and the lengths of the muscle were measured in centimeters.

The third head of the biceps brachii originated from the anterior surface of the capsule of the shoulder joint near greater tubercle. Some part was linked to the tendon of the long head of BBM. And it continued inferiorly $14.7 \mathrm{~cm}$ more between the long and short heads crossing the musculocutaneous nerve (MCN) superficially. And then it merged to the posterior part of the short head at its union with the long head. Its innervation was from the branch of the MCN to the long head of BBM. The blood supply was from a small branch of the brachial artery. No obvious muscle atrophy or pathological findings were observed in this formalinfixed cadaveric specimen. 


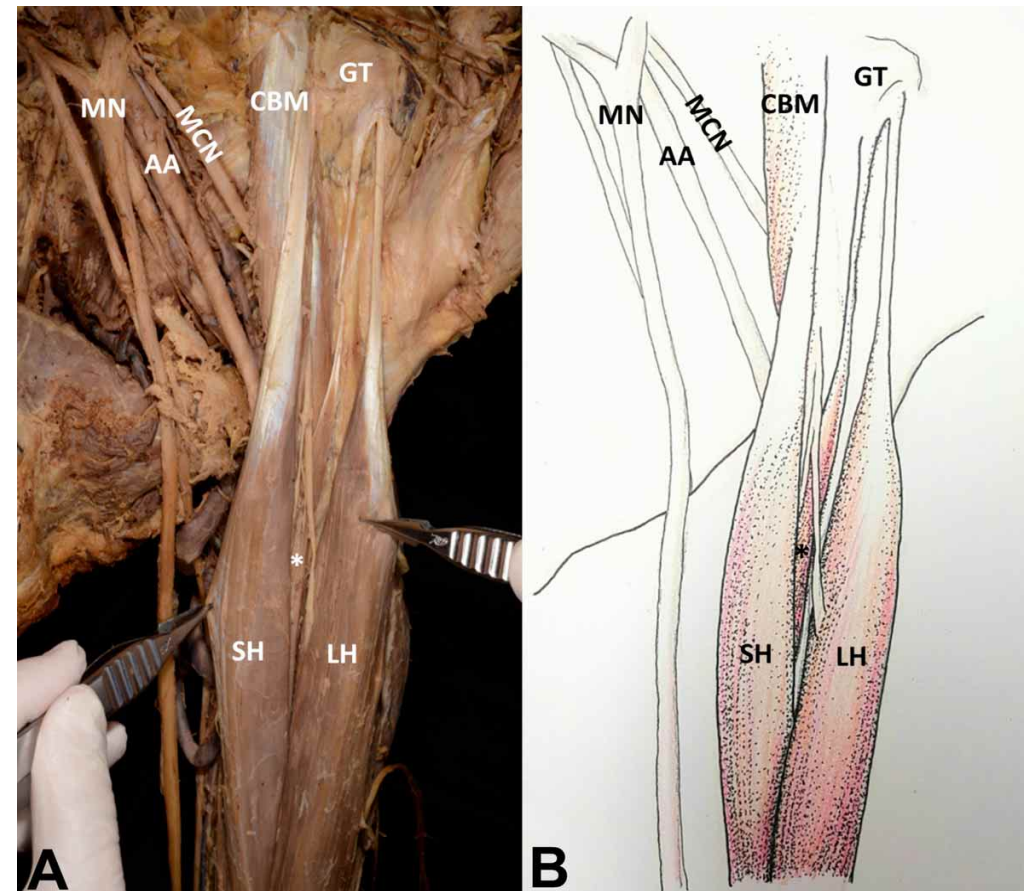

Fig. 1. Photograph (A) and schematic drawing (B) of the third head of the biceps brachii muscle $\left(^{*}\right)$ in the left arm. AA, axillary artery; CBM, coracobrachialis muscle; GT, greater tubercle; $\mathrm{LH}$, long head of the biceps brachii; MCN, musculocutaneous nerve; MN, median nerve; $\mathrm{SH}$, short head of the biceps brachii.

\section{DISCUSSION}

The most frequent variation of BBM is in the number of muscle bellies (Bergman et al.; Asvat et al.; Nakatani et al.; Rodríguez-Niedenführ et al.). In detail, the prevalence of supernumerary heads of BBM was i.e., Chinese $8 \%$, European whites $10 \%$, African black $12 \%$, Japanese $18 \%$, South African blacks 20.5\%, South African whites $8.3 \%$, and Colombian $37.5 \%$ (Bergman et al.; Asvat et al.; Rincón et al., 2002). Lee et al. (2013) found this variation in 14 of $214(6.5 \%)$ in Korean populations and this frequency was lower than that in other races.

Previous studies demonstrated that supernumerary heads of BBM are mostly originated from the infero-medial margin of the humerus (Rodríguez-Niedenführ et al.). Rarely, supernumerary heads originating from the deltoid muscle, the lesser tubercle, intertubercular groove, and the pectoralis major have been reported (Testut, 1883, 1884; Stolowsky, 1899). In present case, third head was originated from the greater tubercle near long head of BBM, which is already reported in previous studies. According to the criteria by Rodriguez-Niedenfuhr et al., this pattern of third head is similar with superior humeral head (1.5\%). Interestingly, it continued obliquely crossing the MCN and it merged to short head of BBM. A third head connection long and short heads is extremely unique and has not been described in Korean population.

In functional aspect, two heads of $\mathrm{BBM}$ have independent actions, therefore, the short head provides some unique functions that are not provided by the long head. Because of the link between long and short heads, a third heads in our case may induce the disorder of supination of the forearm or elbow flexion. And the supernumerary structure in this compartment can cause unexplained symptom by neurovascular compression (Nakatani et al.; Lee et al., 2008). Therefore, clinicians should be aware of this anatomical variation to avoid the misdiagnosis and the complications during surgical interventions.

Here, we reported a third head of BBM originated from the greater tubercle linked to long head and inserted to short head for a first time. Embryologically, during the fifth week of development, mesoderm invades the upper limb bud, to further condense into ventral and dorsal muscle masses (Lee et al., 2014). Supernumerary head of BBM may be originated form the incomplete cleavage of ventral muscle masses by neurovascular structures. Therefore, knowledge of this variation is important not only clinically but also anatomist and further study with larger cases should be performed.

HEO, Y. R.; PARK, J. H.; CHOI, I. J. \& LEE, J. H. Tercera cabeza del músculo bíceps braquial originada en el tubérculo mayor que conecta las cabezas larga y corta: informe de un caso. Int. J. Morphol., 38(1):23-25, 2020.

RESUMEN: La variación en el músculo bíceps braquial es extremadamente frecuente y tiene un significado clínico. Durante una disección educativa, se encontró la tercera cabeza del músculo bíceps braquial en el lado izquierdo de un cadáver coreano. Las cabezas cortas y largas mostraron una morfología y curso normales: sin embargo, la cabeza adicional se originó de la tuberosidad mayor conectado a la cabeza larga del músculo bíceps braquial y cruzaba el nervio musculocutáneo perpendicularmente, insertándose en la cabeza corta del músculo bíceps braquial. El autor describe este informe de un caso novedoso y discute las implicaciones clínicas de tal variante.

PALABRAS CLAVE: Músculo bíceps braquial; Tercera cabeza; Variación. 


\section{REFERENCES}

Asvat, R.; Candler, P. \& Sarmiento, E. E. High incidence of the third head of biceps brachii in South African populations. J. Anat., 182(Pt. 1):1014, 1993.

Bergman, R. A.; Thompson, S. A.; Afifi, A. K. \& Saadeh, F. A. Compendium of Human Anatomic Variation. Baltimore, Urban \& Schwarzenberg, 1988

Je, S. S.; Park, B.; Kim, J. \& Yoon, S. P. Five-headed biceps brachii muscle with a rare origin from the tendon of pectoralis major muscle. Anat. Sci. Int., 91(1):110-3, 2016.

Lee, J. H. The third head of biceps brachii muscle in Korean: Anatomical study. Korean J. Phys. Anthropol., 26(3):97-100, 2013.

Lee, J. H.; Choi, I. J. \& Kim, D. K. The third head of the biceps brachii muscle originated from the pectoralis major muscle. Korean J. Anat. 41:231-2, 2008

Lee, S. H.; Jeon, J. Y. \& Yoon, S. P. A combined variation of the musculocutaneous nerve associated with a supernumerary head of the biceps brachii muscle. Folia Morphol. (Warsz.), 73(3):366-9, 2014.

Nakatani, T.; Tanaka, S. \& Mizukami, S. Bilateral four-headed biceps brachii muscles: the median nerve and brachial artery passing through a tunnel formed by a muscle slip from the accessory head. Clin. Anat., 11(3):209$12,1998$.

Rincón, F.; Rodríquez, Z. I.; Sánchez, A.; León, A. \& González, L. F. The anatomic characteristics of the third head of biceps brachii muscle in Colombian population. Rev. Chil. Anat., 20(2):197-200, 2002.

Rodríguez-Niedenführ, M.; Vázquez, T.; Choi, D.; Parkin, I. \& Sañudo, J. R. Supernumerary humeral heads of the biceps brachii muscle revisited. Clin. Anat., 16(3):197-203, 2003.

Stolowsky, A. Drei seltene Anomalien des M. biceps brachii. Anat. Hefte., 12:299-334, 1899.

Testut, L. Les anomalies musculaires chez l'homme. Paris, Masson, 1884 pp.370-97.

Testut, L. Signification anatomique du chef hume' ral du muscle biceps. Bull. Mem. Soc. Anthropol. Paris, 6:238-45, 1883.
Corresponding author:

Jae-Ho Lee

Department of Anatomy

Keimyung University School of Medicine

2800, Dalgubeoldaero

Dalseo-Gu, Daegu

REPUBLIC OF KOREA

Email: anato82@dsmc.or.kr

Received: 29-08-2018

Accepted: 26-07-2019 